Vol. 7(6), pp. 231-236, June, 2015

DOI: $10.5897 / J D A E 2015.0651$

Article Number: 443AD7753056

ISSN 2006-9774

Copyright@2015

Author(s) retain the copyright of this article

http://www.academicjournals.org/JDAE
Journal of Development and Agricultural Economics

\title{
Effect of Aspillia africana leave on reproduction of rabbit
}

\author{
Adedeji O. A. ${ }^{1 \star}$, Ajibade M. $0 .{ }^{1}$ and Folayan J. A. ${ }^{2}$ \\ ${ }^{1}$ Department of Animal Science and Production, Joseph Ayo Babalola University Ikeji Arakeji. P. M. B. 5006 llesa, Osun \\ State, Nigeria. \\ ${ }^{2}$ Department of Agricultural Economic and Extension, Joseph Ayo Babalola University Ikeji Arakeji. P. M. B. 5006 Ilesa, \\ Osun State, Nigeria.
}

Received 25 March, 2015; Accepted 12 May, 2015

\begin{abstract}
This study investigated the effect of Aspillia africana leaves on reproduction of rabbit and was conducted at the rabbit section of the University Teaching and Research Farm of Joseph Ayo Babalola University Ikeji-Arakeji Osun State, Nigeria. The experiment has a complete randomized design with four treatments and one control. Each treatment has two replicates as well as the control. Twenty-four (24) cross-breed (New Zealand White and Flemish) rabbits were used. (Twenty primiparous Does, and four bucks). The $A$. africana leave was harvested and sun dried and then grinded into powder form in the laboratory. The grinded leave of $A$. africana was mixed with concentrate from a reputable feed mill in Nigeria in ratio of Concentrate: Aspillia leaves treatments and control allocated. Treatment A (80:20), Treatment B (60:40) Treatment C (40:60), Treatment D (20:80) and control (100:0). The average weekly weight gain, gestation period, birth weight, weight at parturition, litter size and survival of the does were taken and computed for statistical analysis. Among the treatments, Treatment $\mathrm{C}$ showed a higher birth weight, implying a better conversion and utilization of the feed (Concentrate (40\%): $A$. africana dried leave $(60 \%)$ combination) by the fetus with average birth weight of $42.50 \mathrm{~g}$. Analysis of the feed composition also showed $24.25 \%$ protein, and the energy $2942.69 \mathrm{ME} / \mathrm{kcal}$. The use of $A$. africana dried leave can be safely used, and recommended as observed at the level of inclusion in Group C treatment in this study, especially in the dry season to the farmers to upgrade the reproductive potential of their rabbits.
\end{abstract}

Key words: Rabbit, Aspillia africana leave, effect, reproduction.

\section{INTRODUCTION}

Rabbit production is one of the livestock enterprises with the greatest potential and opportunity for expansion in Nigeria. A domestic rabbit (Oryctolagus cuniculus) can be a great source of meat, if its production is encouraged amongst livestock producers.

The world production of rabbit meat is estimated (Anon,

*Corresponding author. E-mail: atanda@ymail.com

Author(s) agree that this article remain permanently open access under the terms of the Creative Commons Attribution License 4.0 International License 
1994) to be 1.5 million tons per annum. This would mean per caput annual consumption of $280 \mathrm{~g}$ per person per year (Moreki, 2007). The five major world's rabbit producing countries are Italy, Commonwealth of Independent States (Russia and the Ukraine), France, China and Spain. In Africa, the leading rabbit producing countries are Morocco and Nigeria and these are reported to produce 20000 to 99000 tons meat per year.

It has been estimated that the daily minimum crude protein requirement of an adult in Nigeria varies between 65 and $85 \mathrm{~g}$ per person. However, it is recommended that $35 \mathrm{~g}$ of this minimum requirement should be obtained from animal products (Oloyede, 2005).

Rabbits are ideal small livestock project for peri-urban or rural areas, especially in developing countries such as Nigeria, Botswana etc. with a significant proportion of citizenry living below poverty datum line. They are quite clean and relatively odourless. The raising of rabbits can be anything from a profitable hobby to a fulltime living and can readily serve to complement other livestock, such as Poultry, Fish, and Piggery etc as source of animal protein. Rabbits fit well into a balanced farming system and its initial investment is minimal when compared with other types of livestock. Their conversion rate of local feeds e.g. grains, greens and left-over food to quality meat is high even as these feed are within the reach of farmers. They complement well with vegetable growing. Excess and waste from vegetable gardens and kitchen goes to feed the rabbits, whereas their manure is used to fertilize gardens, thus forming a profitable cycle and aiding the balance of nature.

In Nigeria, it is of interest that rabbit farming is still on small scale or backyard production. Even at this level, productivity, survival rate and availability of forages during dry season are still a big challenge to farmers, especially forages that can satisfy their fiber requirement, but they are widely distributed and available during the raining season.

The nutritional and the medicinal importance of Aspillia africana leave has been established, it is called hemorrhage plant which serves as an antimalaria (Waako et al., 2005) and anti viral (Okoli et al., 2007) widespread in Africa. It is used in traditional medicine to stop bleeding from wound, clean the surfaces of sores, treatment of rheumatic pains, bees and scorpion stings and for removal of opacities and foreign bodies from the eyes (Okoli et al., 2007). The effect of $A$. africana leave on reproduction is not well documented, however unauthenticated information in some communities in Nigeria said it prevent conception when boiled, alleviate menstrual cramps and dysmenorrheal.

The global interest in search for anti-microbial substances from natural sources has led to increase investigation of more plants than before (Fasola and lyamah, 2014). Andrade-Neto et al. (2003) investigated some plant parts commonly used in the treatment of Malaria and observed that, the medicinal values of plants and their component phytochemicals such as alkaloids, tannins, flavonoids, phenolics and other compounds have been found to produce a definite physiological action on human body. A systematic search for useful bioactivities from medicinal plants is now considered to be a rational approach in nutraceutical and drug research. The presence of antioxidants and phytochemicals in Blueberries (Zegarac, 2014) is associated with cardiovascular and cognitive health, cancer and diabetes prevention, others include Adansonia digitata, Alstonia congeensis, Khaya senegalensis (Coker et al., 2000), Tithonia diversifolia (Oyewole et al., 2008; Fasola and lyamah, 2014).

$A$. africana is one of the many indigenous plant used by trado-medical practitioners in Nigeria to cure certain illness and posses the ability to stop bleeding, block infection and quick wound healing. The plant is popularly known as "hemorrhage plant" (Okwute, 1998). It is known as organgilia in Ibo, Tanzanian in Hausa, Yungun in Yoruba and Edemedong in Efik (Single, 1965). It is a common weed of field crops in west Africa found in fallow land almost everywhere especially in the forest zone. It is a scrambling perennial herb varying in height from $60 \mathrm{~cm}$ to about $1.5 \mathrm{~m}$ depending on the amount of rainfall (Akobundu and Agyakwa, 2011). The flowers are bright yellowish florets and the fruits are bristly and minutely hairy with four (4) angled schemes about $5 \mathrm{~mm}$ long.

$A$. africana has also been reported by Okoli et al. (2007) that the leaves has many other additional uses such as palliative properties because its chemical constituents are capable of arresting wound bleeding, inhibiting the growth of microbial wound contaminants and accelerating wound healing. In Kenya, they are used to kill intestinal worms, in Uganda it is used to treat gonorrhea (Okoli et al., 2007). The methanol extract of the leaves are reported to cure malaria and respiratory problems (Fasola and lyamah, 2014). A concussion of the leave are used to cure eye problem and as a lotion for the face to relieve febrile headache.

Despite the acclaimed importance of the leaves of $A$. africana based on its medicinal advantage reported by many scholars and researchers, the information about its nutritional constituents as well as its effect on the reproductive performance of rabbit is scarce in spite of its wide distribution and availability in Africa.

In Africa, most rabbit keepers or rabbit farms are not large or economically viable enough to justify the use of several or different rations in feeding rabbit. It is a common practice to use just one compounded diet or domestic remnants for the entire herds. To obtain effective performance and feed efficiency, diet should be formulated to meet the needs of animal particularly age or stage of production. It is of great importance that feed given to rabbit must ensure good maintenance, and high productivity, taking into consideration the effective utilization of the feed, sound reproductive performance, in term of fertility, gestation period, parity, birth weight and 
survival rate of the litters as well as profitability. This is the main focus of this research.

\section{Objective of the Study}

The major objectives are:

i. To establish the effect of $A$. africana leaves on reproductive performance of rabbit, taking into consideration the gestation length, parity, birth weight, litter size and survival rate of the kids.

ii. To establish the need for the inclusion of $A$. africana leaves in rabbit feed.

iii. To ascertain the most economic level of inclusion for high productivity.

\section{Problem statements}

There is low reproductive performance of rabbit in the tropics which has reduced interest of farmers going into its production. The information on the reproductive potential of rabbit fed $A$. africana leaves is scanty.

\section{MATERIALS AND METHODS}

\section{Research site}

The study was carried out on the Rabbit Unit of The Teaching and Research farm Joseph Ayo Babalola University, Ikeji-Arakeji Osun State, Nigeria. Joseph Ayo Babalola University is situated in Oriade Local Government Area (LGA) of Osun State in South Western Nigeria. The Local Government has an area of $465 \mathrm{~km}^{2}$ with population of 148,617 (Andrade-Neto et al., 2003). It is predominantly occupied by the ljesa people. Its capital is ljebu-Jesa (or ljebu ljesha) in the north of the area at $7^{\circ} 41^{\prime} 00^{\prime \prime} \mathrm{N} 4^{\circ} 49^{\prime} 00^{\prime \prime} \mathrm{E}$ / $7.68333^{\circ} \mathrm{N} 4.81667^{\circ} \mathrm{E}$. It is situated in the tropical rain forest zone, with scattered swamps, rivers, waterfall and living springs in Erinljesha, a town in the local Government that serves as a tourist center. The soil is fertile and encourages the cultivation of various types of food and industrial crops (Zegarac, 2014).

\section{Statistical analysis}

All data collected were subjected to analysis of variance (ANOVA) using the procedure of SAS Institute Inc. SAS/STAT Users Guide (1999). Significant difference mean values were compared using the Duncan Multiple Range Test.

\section{Experimental animals and management}

Twenty-four rabbits (twenty primiparous Does and four Bucks) were used for the experiment. They were sourced locally from domestic backyard Rabbit farmers, in towns around Joseph Ayo Babalola University Ikeji-Arakeji Osun State, Nigeria, where the research was carried out. The Does were selected randomly and not specie based. They were allocated into hutches at four does per treatment in two replicate. The experiment has four treatments and one control. Each treatment has two replicate and contain two Does per
Table 1. Ratio of test and control feed mixture.

\begin{tabular}{lc}
\hline Treatment & Ratio of feed mixture \\
\hline A & $80: 20$ \\
B & $60: 40$ \\
C & $40: 60$ \\
D & $20: 80$ \\
Control & $100: 0$ \\
\hline
\end{tabular}

replicate in one treatment making four Does in one treatment. The initial weights of the rabbits were taken to measure the body weight gain on weekly basis. They were fed with the prepared ration for two weeks to acclimatize and treated for five days with antibiotics and ivermectin based injectable.

\section{Test materials and diet}

Two feeds were use for this experiment, the plant forage leaves of $A$. africana. The leave was sun-dried and grinded into powdered form in the laboratory, and a standard poultry grower's mash as concentrates (from a renowned commercial feed mill company in Nigeria). The grinded dried leave of $A$. africana and the concentrates were mixed in the ratio of Concentrate: $A$. africana leave for the four treatments and control as shown in Table 1. Table 2 shows the proximate analysis of the feed samples in ratio as mixed per treatments as well as the analysis of the grinded leave of A. africana.

The daily ration fed to the rabbit was measured by using the weight of the biggest doe. The biggest doe used for the experiment was the giant Flemish which weighs $2.51 \mathrm{~kg} .5 \%$ of the weight was taken as daily ration feed measurement fed to the rabbits. 5/100 $\times$ $2.51=0.13 \mathrm{~kg}$ Approx. $0.13 \mathrm{~kg}$. This form the daily ration fed to each doe and later increase by $10 \%$ during pregnancy.

The rabbits were stabilized on the prepared feeds for two weeks with an accurate weight gain taken on weekly basis. After two weeks of acclimatization with the experimental feed, the Does were introduced to the Buck for mating, and observed for two weeks for pregnancy through gentle abdominal palpation, increment in body weight and refusal to accept Buck.

The gestation period was observed and recorded per Doe in each treatments as well as the control. The birth weight of each kit was taken and recorded within twenty-four hours of kindling as well as the weight of the mother Doe after parturition.

\section{RESULTS AND DISCUSSION}

The performance test of $A$. africana leaves on reproduction of rabbit using different treatments and parameters are presented in Tables 3, 4, Figures 1 and 2. The parameters used as basis of data and record are weight before mating (WTBM), weight after mating (WTAM), birth weight (BIRTHWT) litter size, weight at parturition (WTPPAT) gestational period and survival rate (SURV RATE). There are four treatments and one control, with two replicates in each treatment. The test leave of $A$. africana and concentrate used were given in five different ratios of (Concentrate: $A$. africana leave). Treatment A (80:20), Treatment B (60:40), Treatment C 
Table 2. Proximate analysis of feed sample.

\begin{tabular}{|c|c|c|c|c|c|c|c|}
\hline Sample & $\%$ Ash & $\%$ Crude protein & $\%$ Crude fibre & $\%$ Ether extract & $\%$ Dry matter & Gross (kcal/g) & ME (kcal/kg) \\
\hline TRT1 & 8.50 & 23.80 & 12.00 & 8.00 & 91.56 & 4.316 & 3005.13 \\
\hline TRT2 & 11.00 & 24.15 & 15.00 & 7.00 & 91.98 & 4.318 & 3044.43 \\
\hline TRT3 & 6.50 & 24.25 & 15.00 & 7.00 & 92.13 & 4.321 & 2942.69 \\
\hline TRT4 & 8.00 & 22.71 & 20.00 & 7.00 & 92.18 & 4.310 & 2764.66 \\
\hline TRT100 & 7.30 & 21.00 & 10.00 & 8.00 & 92.01 & 4.300 & 3192.86 \\
\hline Grinded Aspillia leave & 15.00 & 20.65 & 14.00 & 8.00 & 91.25 & 3.716 & 2861.63 \\
\hline
\end{tabular}

Source: University of Ibadan, Nigeria. Laboratory Department Faculty of Animal science. Keys: TRT1-4 = Test treatment; TRT100 = Control treatment.

Table 3. The weekly weight gain by rabbit does.

\begin{tabular}{|c|c|c|c|c|c|c|c|}
\hline Variable & Mean & Standard deviation & Standard error & Coefficient of variation & Range & Minimum & Maximum \\
\hline WTBM & 1.8 & 0.33 & 0.09 & 18.07 & 1.1 & 1.3 & 2.4 \\
\hline WTAMWK_1 & 1.7 & 0.59 & 0.16 & 34.52 & 2.45 & 0 & 2.45 \\
\hline WTAMWK_2 & 1.77 & 0.61 & 0.17 & 34.56 & 2.4 & 0 & 2.4 \\
\hline WTAMWK_3 & 1.81 & 0.63 & 0.18 & 34.95 & 2.5 & 0 & 2.5 \\
\hline WTAMWK_4 & 1.86 & 0.64 & 0.18 & 34.52 & 2.6 & 0 & 2.6 \\
\hline WTPPAT & 1.34 & 0.82 & 0.24 & 61.4 & 2.15 & 0 & 2.15 \\
\hline GESTATION & 21.92 & 13.35 & 3.85 & 60.92 & 32 & 0 & 7 \\
\hline LITTER SIZE & 2.58 & 2.43 & 0.7 & 94.04 & 7 & 0 & 7 \\
\hline BIRTHWT & 23.54 & 18.11 & 5.23 & 76.91 & 42.5 & 0 & 42.5 \\
\hline SURV RATE & 1.54 & 2.3 & 0.64 & 149.21 & 6 & 0 & 6 \\
\hline
\end{tabular}

Keys: WTBM = Weight before mating; WTAMWK1-4 = Weight after mating week one to four; WAPPT = Weight at parturition; BIRTHWT = Birth weight; SURV RATE = Survival rate.

(40:60), Treatment $D(20: 80)$ and Control (100:0). The weight of the Does in all the treatments is not significantly different $(p>0.05)$ WTBM and WTAM but increases progressively from WTAMWK1WTAMWK4 (Table 3 and Figure 1).

The gestation period in all the treatment is similar with Treatments $C$ and $D$ having a higher number of days (Table 4 and Figure 2). The litter size also differ with Treatments A, C and control having a higher size (Table 3 ). The average birth weight of the kits is highest in Treatment B and C, but with lowest survival rate (Table 3 ).

In this research, it was discovered that the rabbit Does placed on four treatments (in different ratio of the leave and concentrate) were mated, became pregnant and carried the pregnancy to term (28 to 32 days) with an average gestation period of 30 days, this is in agreement with 31 days observed by (Moreki, 2007).

The result also showed a negative relationship between the birth weight and the litter size in Treatments A, B, C and D, in agreement with Zerrrouki et al. (2004) and Prayaga and Eady (2012) reports, that the larger the litter size, the smaller the birth weight. However, the survival rate was significant $(P<0.05)$.

The Gestation period (29.5, 32 and 30 days) and litter size $(4.5,3.0$, and 3.33) for Treatments $\mathrm{A}, \mathrm{C}$, and control respectively (Table 4 and Figure 2) showed a similar reproductive response, 
Table 4. The reproductive performance of rabbit does.

\begin{tabular}{lccccc}
\hline Treatment & WtPPat & Gestation & Litter size & Birthwt & Surv rate \\
\hline A & 1.95 & $29 . S 0$ & 4.50 & 23.33 & 2.67 \\
B & 1.65 & 28.00 & 1.33 & 32.50 & 0.33 \\
C & 1.85 & 32.00 & 3.00 & 42.50 & 0.00 \\
D & 0.62 & 28.00 & 1.67 & 13.33 & 0.33 \\
CONTROL & 1.18 & 30.00 & 3.33 & 21.67 & 3.33 \\
MEAN & 1.45 & 23.77 & 2.77 & 26.67 & 1.33 \\
CV\% & 38.0 & 38.9 & 46.6 & 41.9 & 115.9 \\
SE & 0.28 & 4.62 & 0.64 & 5.58 & 0.77 \\
\hline
\end{tabular}

Keys: WtPPat $=$ Weight at parturition; Gestation = Gestation period; Littersize $=$ Litter size; Birthwt $=$ Birth weight and SurvRate $=$ Survival rate.

weight in weeks

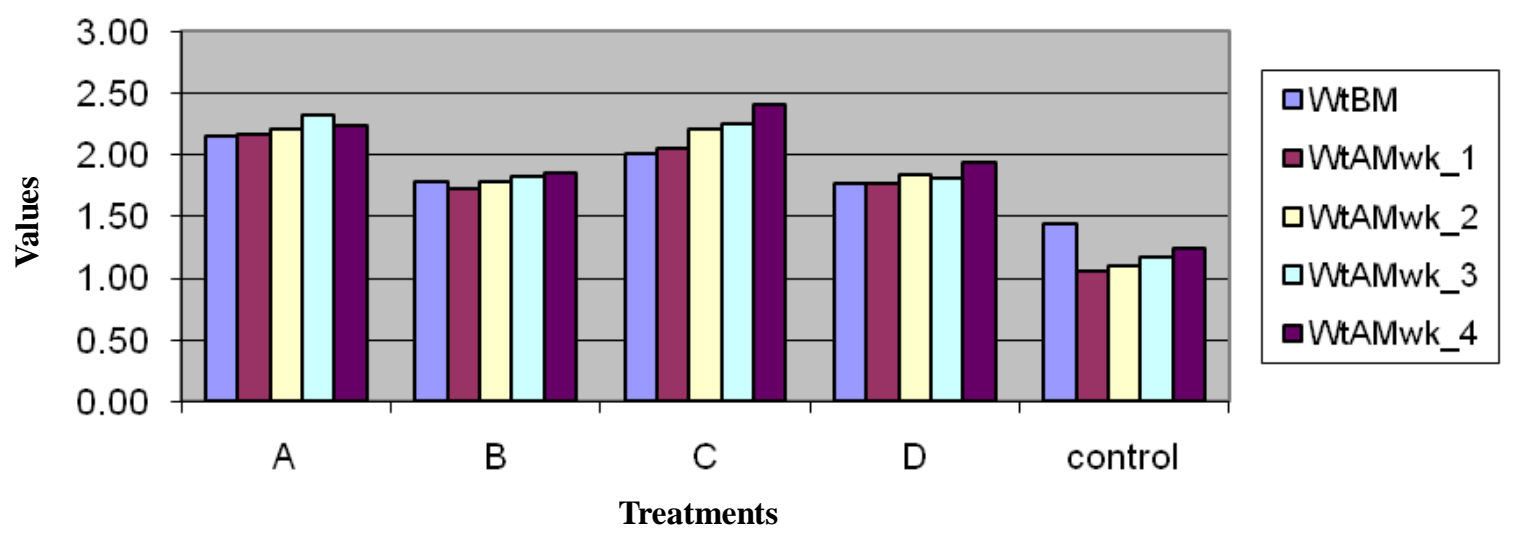

Figure 1. Graph showing the weight gain in weeks of does. Keys: WTBM = Weight before mating; WTAMWK1-4 = Weight after mating week one to four.

Title

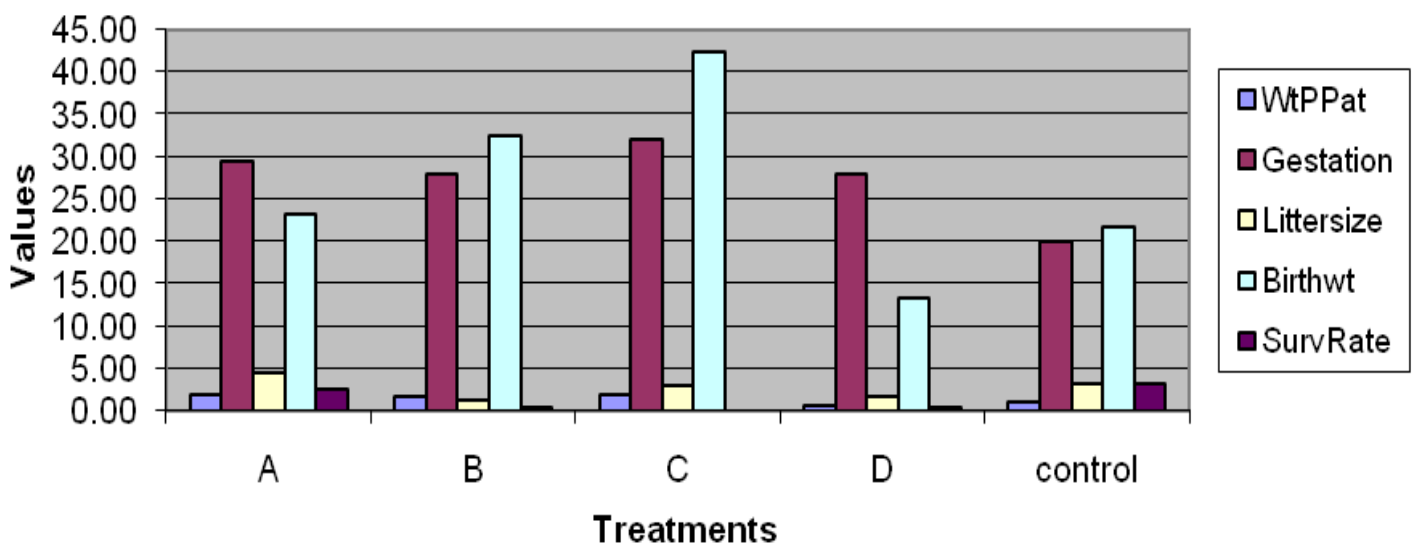

Figure 2. Graph Showing the Reproductive Performance of Rabbit Does. Keys: WtPPat = Weight at parturition; Gestation = Gestation period; Littersize $=$ Litter size; Birthwt $=$ Birth weight and SurvRate $=$ Survival rate. 
indicating that rabbit will perform well on any of the three treatments. Among the three treatments, Treatment $\mathrm{C}$ showed a higher birth weight, implying a better conversion and utilization of the feed (Concentrate $(40 \%)$ : $A$. africana dried leave $(60 \%)$ combination) by the fetus.

The $42.50 \mathrm{~g}$ average birth weight observed (Treatment C) is in agreement with the Zerrrouki et al. (2004) report, that the average weight of young rabbits at birth was 51 g. and that for survivability of the kitten, it should have at least $40 \mathrm{~g}$ body weight at the time of birth, and broiler rabbits kitten between 40 to $50 \mathrm{~g}$ or more.

The lower survival rate experienced with Treatment $\mathrm{C}$ can be ascribed to the inability of the mother Doe to shed its fur for the kitten to prevent unfavorable environmental condition, as observed in this treatment, this is common with primiparous Doe (Moreki, 2007), hence the inability of the kitten to survive.

\section{CONCLUSION AND RECOMMENDATION}

The composition of the feed in Treatment $\mathrm{C}$ among other values showed $24.25 \%$ protein and the energy 2942.69 $\mathrm{ME} / \mathrm{kcal}$ as shown in Table 2 indicate that the feed is nutritious, hence the higher average litter size and birth weight observed compared to other groups.

The use of $A$. africana dried leave can be safely used, and recommended as observed at the level of inclusion in this Group, especially in the dry season to upgrade the reproductive performance of rabbits. The plant is a weed, palatable to rabbits, readily available and cost little or nothing to get in this part of the world, especially during the raining season; it can be harvested, dried, and stored for use even at commercial level.

\section{Conflict of Interest}

The authors have not declared any conflict of interest.

\section{REFERENCES}

Anon (1994). Rabbit production. Agricultural Alternatives. College of Agricultural Sciences, Cooperative Extension, Pennsylvania State University.

Oloyede HOB (2005). All for the love of nutrients. The seventy eight inaugural lecture, Library and publication Committee, University of llorin.

Waako PJ, Smith P, Folb PI (2005). In vitro interactions of Aspilia africana (Pers) C D. Adams, a traditional antimalarial medicinal plant, with artemisinin against Plamodium falciparum. J. Ethnopharmacol. 102:262-268.
Okoli CO, Akah PA, Okoli AS (2007). Pottential of leaves of Aspillia Africana (compositae) in wound care: An experimental evaluation. BMC Complement. Altern. Med. pp. 7-24

Fasola TR, lyamah PC (2014). Comparing the Phytochemical Composition of Some Plant Parts Commonly Used in the Treatment of Malaria. Int. J. Pure Appl. Sci. Technol. 21(1):1.

Andrade-Neto VF, Brandão MG, Stehmann JR, Oliveira LA, Krettli AU (2003). Antimalarial activity of Cinchona-like plants used to treat fever and malaria in Brazil. J. Ethnopharmacol. 87(2-3):253-256.

Zegarac JP (2014). The Power of Blueberries Today's Dietitian 16(10):42.

Coker HAB, Chukwuanim CM, Ifudu ND, Aina BA (2000). The malaria scourge: Concept in disease management. Niger. J. Pharm. 32:1947.

Oyewole IO, Ibidapo CA, Moronkola DO, Oduola AO, Adeoye GO, Anyasor GN, Obansa JA (2008). Antimalarial and repellant activities of Tithonia diversifolia (Hemsl) leaf extracts. J. Med. Plants Res. 2(8):171-175.

Okwute SU (1998). Antimicrobial and Phytochemical screening of dabergin sexatilix Vol 1JPAS Zumas Abuja Ngeria.

Single (1965). Tribal names of Aspilia Afrcana. Agric. J. 6(1):28-30.

Akobundu IO, Agyakwa CW (2011). A handbook of West African weed International institute of Tropical Agriculture (IITA), Ibadan Nigeria. Agric. J. 6(1):28-30.

SAS Institute Inc (1999). SAS/STAT Users Guide. Version 8 for windows. SAS Institute Inc., SAS Campus Drive, Cary, North Carolina, USA.

Zerrouki N, Bolet G, Berchiche M, Lebas F (2004). Breeding performance of local Kabylian rabbits does in Algeria. In Proc.: 8th World Rabbit Congress, Puebla, Mexico pp. 7-10, 371-377.

Prayaga KC, Eady SJ (2012). Factors affecting litter size and birth weight in rabbits. Proc. Assoc. Adv. Anim. Breed. Genet. 14:59.

Moreki JC (2007). Commercial Rabbit Production. Rabbits Today Rab 01 June 2007. 